\title{
Digital Transformation: Opportunity or Threat to Employability?
}

\author{
Rolando Rojas Romero ${ }^{1}$ \\ Héctor Valdés-González ${ }^{2}$ \\ Lorenzo Reyes-Bozo ${ }^{3}$
}

Received: April 15, 2021

Accepted: May 13, 2021

Published: May 24, 2021

Citation: R. Rojas-Romero, H. Valdés-González, L. Reyes-Bozo, "Digital Transformation: Opportunity or Threat to Employability?," Revista Facultad de Ingeniería, vol. 30 (56), e13297, 2021. https://doi.org/10.19053/01211129.v30.n56.2021.13297

\section{Abstract}

This paper presents a critical analysis of the Digital Transformation's (DT) effects on employability within organizations in Chile, providing an action reference framework for competitiveness in the field. To achieve this, a qualitative approach to the opinions of a convenience sample of executives and leaders was employed, based on semi-structured interviews, to understand how to address this type of transformation. The analysis indicates that, having long-term policies for the development of new skills in their collaborators is a critical success factor. These policies are summarized in three stages, through a reference framework for the

\footnotetext{
${ }_{1}^{1}$ M. Sc. Universidad del Desarrollo (Santiago, Chile). rorojasr@udd.cl.

2 Ph. D. Universidad del Desarrollo (Santiago, Chile). hvaldes@udd.cl. ORCID: 0000-0002-3754-6862

3 Ph. D. Universidad Autónoma de Chile (Santiago, Chile). lorenzo.reyes@uautonoma.cl. ORCID: 0000-00024523-0139
} 
generation of specific actions in pursuit of the development of a successful DT process. DT fosters a cultural change in the entities to generate capacities that allow them to anticipate the evolution of the market and adapt quickly to it, for which it is fundamental to promote the training of new technical and behavioral skills in collaborators, in addition to encouraging them to self-train.

Keywords: fourth industrial revolution; reskilling; skills; talent management; upskilling.

\section{Transformación Digital: ¿Oportunidad o amenaza sobre la empleabilidad?}

\section{Resumen}

Este trabajo presenta una mirada crítica de cómo la Transformación Digital (TD) influye sobre la empleabilidad al interior de las organizaciones en Chile. El presente trabajo tiene por objeto analizar los efectos de la Transformación Digital sobre la empleabilidad en Chile, entregando un marco de referencia de acciones para la competitividad en el ámbito de este tipo de transformaciones. Para lograrlo, se propone una aproximación cualitativa a las opiniones de ejecutivos y líderes, basada en entrevistas semiestructuradas, considerando una muestra por conveniencia, para entender qué y cómo la organización analizada aborda este tipo de transformación. El análisis señala como factor crítico de éxito en las organizaciones, disponer de políticas de largo plazo para el desarrollo de nuevas habilidades en sus colaboradores, resumidas en tres etapas concretas, por medio de un marco de referencias para la generación de acciones específicas en pos del desarrollo de un proceso exitoso de TD. La TD propicia un cambio cultural en las entidades con el fin de permitirles generar capacidades para anticipar la evolución del mercado y adaptarse ágilmente a este, siendo para ello fundamental potenciar la formación de nuevas habilidades técnicas y del comportamiento en sus colaboradores, además de incentivarlos a la autoformación.

Palabras clave: cuarta revolución industrial; gestión del talento; habilidades; reskilling; upskilling. 


\section{Transformação digital: oportunidade ou ameaça à empregabilidade?}

\section{Resumo}

Este trabalho apresenta uma visão crítica de como a Transformação Digital (TD) influencia a empregabilidade nas organizações no Chile. O presente trabalho tem como objetivo analisar os efeitos da Transformação Digital sobre a empregabilidade no Chile, fornecendo um quadro de referência para ações de competitividade no campo deste tipo de transformação. Para tanto, propõe-se uma abordagem qualitativa das opiniões de executivos e líderes, a partir de entrevistas semiestruturadas, considerando uma amostra de conveniência, para entender o que e como a organização analisada aborda esse tipo de transformação. A análise aponta como fator crítico de sucesso nas organizações, possuindo políticas de longo prazo para o desenvolvimento de novas competências em seus colaboradores, sintetizadas em três etapas específicas, por meio de um quadro de referências para a geração de ações específicas na busca do desenvolvimento de uma Processo TD. A TD promove uma mudança cultural nas entidades de forma a permitir-Ihes gerar capacidades para se antecipar à evolução do mercado e a ele se adaptarem rapidamente, sendo para isso fundamental promover a formação de novas competências técnicas e comportamentais nos seus colaboradores, para além de encorajando-os ao autotreinamento.

Palavras-chave: gestão de talentos; habilidades; quarta revolução industrial; requalificação. 


\section{INTRODUCTION}

The different media often feature headlines warning about job continuity as a result of jobs being replaced by automation or adoption of new technologies. However, the latest report from the World Economic Forum mentions that by $202210 \%$ of employment reduction caused by automation will be compensated by an increase of $11 \%$ in the creation of new jobs and professions [1]. Technology has contributed to the increase in productivity as well as to the improvement of people's wellbeing [2]. The development attained since the First Industrial Revolution has been significant and has led us to what experts call the Fourth Industrial Revolution, or, more focused on the economic field, known as Digital Transformation (DT) where technologies such as Artificial Intelligence (Al), Internet of Things (loT), Big Data, Block Chain, etc., pose a series of opportunities and challenges to the organizations [2,3]. Today, the exact impact the DT phenomenon will have on business is yet unknown. For our country (Chile), DT is not a foreign phenomenon, though its application in the local context is incipient. It is crucial to conduct studies for the early detection of the skills that need to be developed, as well as those that will be replaced, as this will create policies and good practices to positively impact the productivity of the organizations and the workforce employability.

\section{A. Representation Models or Types}

This study ordered by the Economic Commission for Latin America and the Caribbean (ECLAC) interprets the problem by analyzing the human capital gap in Latin America regarding the stages of the technological cycle and the evolution in the digitalization waves [4]. The study discusses the offer of education programs in digitalization, considering its degree of advance and insertion. At the same time, in its latest report called "The Future of Jobs Report 2018", the WEF [1] suggests some questions for five years that governments, companies and workers might ask themselves on the transformation of the local market due to technological processes. To draft this report, managers of the main employers in the world were interviewed to obtain projections regarding jobs and skills in the context of the problems with a horizon to the year 2022. It was obtained, unlike other studies conducted with a more 
extensive projection horizon, a projection for an "operational profile", as the author himself calls it, to be considered. As part of the methodology, the report uses the Occupational Information Network (O*NET) classification of jobs, tasks and skills.

\section{B. How do Other Countries in the World Deal with This Topic?}

For Spain, a revision of recent literature on the influence of business digitalization in the Spanish labor market is suggested [5]. The author performs a historical overview and presents an analysis of the different authors writing on the problem of jobs being substituted by technology. He particularly highlights Autor et al. contribution as a canonic analysis model for the relation between job demand and qualification, by classifying routine tasks and non-routine tasks and how these have experienced changes in their growth rate inversely, the non-routine tasks grow because, according to the author, they are less likely to be copied by a technological element such as Robotic Automation Process (RPA) [6].

For Germany [7], the difference between tasks and occupations in the German contexts where tasks are likely to be substituted by technology is explored. Considering that a group of tasks shape an occupation, he asserts that occupations would be less likely to be entirely substituted by technology than as suggested in previous studies. The results delivered by the study are a prognosis with data up to 2013 of the occupations substitutable by technology in the German labor market, such as works in manufacturing and basic and repetitive human interaction in processes that use technology.

In Latin America a vision of DT in Uruguay is provided [8]. The analysis considers entities such as the state, companies, trade unions, and the population in general, and concludes with an important negative alarmist social effect. Through examples and practices in companies, proposes how digital leaders use specific leverage (diverse and specific composition of the team, establishment of iterative goals, continuous learning and talent management) to drive organizations towards a successful DT [2]. In turn, Tekic et al. [3], work shows how to identify own and distinctive strategies for DT, expressed along two critical dimensions: the use of digital technology and a business model for operation in digitalization environments. 
Moreover, it presents a typology of generic digital transformation strategies based on leadership style, the importance of skills associated with creativity and entrepreneurship among collaborators, risks, challenges and consequences of a failure, and tactics available to improve the DT process itself.

\section{How does Chile deal with DT?}

Studies in Chile are emerging [4], asserts that the offer of educational material in DT is limited, particularly in $\mathrm{PhD}$ programs, which the author interprets as a difficulty when research and education of teachers in the subject is required. This study proposes to include information technology as a basic subject at schools. In line with the skills a qualified workforce should have, the Organization for Economic Cooperation and Development (OECD) assesses the degree of alignment between supply and demand of skills in the Chilean labor market, focusing on less privileged sectors [9]. The study uses the Adult Skills Survey (known as PIAAC) as the methodology which gives poor results for Chile compared to other OECD countries. The study emphasizes the relevance the skills have on the labor market and the need to more frequently retrain the active workforce. It also recommends investing in the quality of education and training in this segment.

We can also consider the document published by the Santiago Chamber of Commerce (CCS by its acronym in Spanish) together with the consulting company PMG [10], on the degree of comprehension of DT and the related strategies companies have at a local level. Regarding maturity in this area, the Chilean companies considered were classified by the author as "Digital Beginners".

Considering the bibliographical revision above, we can ask the following question: How does development in digital transformation affect employability? There seems to be a relation between these two variables (DT and unemployment) and this work explores and analyzes it.

One of the motivations to conduct this study was to understand which skills should the workforce develop to maintain or improve its employability level. It also seeks to propose a reference framework of specific actions to foster company-country competitiveness considering the internal social effects of the DT. 


\section{Methodology}

Paradigm and Design: A qualitative methodology based on semi-structural interviews was used, as this methodology enables scientific rigor in the deep understanding of participants' perceptions [11].

Sample: A convenience sample of 13 different stakeholders was used, including influential executives and leaders, from a communications and digital actions company in Chile. The typical-case criterion enabled the selection of managers who represented $20 \%$ of the sample. The rest of the sample consisted of department managers $(30 \%)$, department heads $(30 \%)$ engineers and professionals with over 40 years of work experience $(10 \%)$, and trade union stakeholders $(10 \%)$. The participants had spent, on average, 22 years in the organization where the study was conducted, the person with the highest seniority had 47 years of experience and the person with lowest seniority 9 years of experience. $50 \%$ of them has worked mainly in matters related to DT in recent years.

Context: The selected context is the Network Operations Management of a wellknown telecommunication company in Chile. The department is conformed by over 800 employees throughout the country and concentrates close to $80 \%$ of the company's OPEX budget. The average age (56 years old) of the department indicates an important experience in previous transformation processes.

Interventions: In order to develop the interview questions, the department's buildings were visited and non-participant observations were carried out. During the interviews, a written document with questions was used to guide the discussion, together with a device to record the conversations. The 12 questions were openended [11], and grouped according to the three stages: Stage 1, Characterization of the present and understanding of reality; Stage 2, High-impact proposals; and Stage 3, Alerts on transformation. Simultaneously, the researcher kept a written record with the summary, notes and other situations observed throughout the interviews as well as the perceptions of the environment and the facilities of the studied organization. The interviews were transcribed prior to its analysis. 
Ethics: Participation was informed and voluntary; a signed consent was obtained. Measures to ensure information confidentiality were taken and checked with the participants. No implicit nor explicit attempt to influence the answers nor change the individual features was made; freedom to participate was accepted without pressure or offering benefits for participation.

\section{RESULTS}

Table 1 outlines the skills mentioned by the interviewees that can be contrasted with Table 2.

Table 1. Skills mentioned by the interviewees.

\begin{tabular}{|l|}
\hline \multicolumn{1}{|c|}{ Skills } \\
\hline Flexibility; Capacity to Adapt; Communication; Collaboration; Attitude and willingness to change; \\
Self-learning; Empathy; Multiskilling in specific knowledge; Leadership
\end{tabular}

Table 2. Skills proposed by the WEF [1].

\begin{tabular}{|l|c|}
\hline \multicolumn{1}{|c|}{ Skills } & Frequency \\
\hline Emotional intelligence & $40 \%$ \\
\hline Active learning and learning strategies & $20 \%$ \\
\hline Creativity, originality and initiative & $10 \%$ \\
\hline Technology design and programming & $10 \%$ \\
\hline Critical thinking and analysis & $10 \%$ \\
\hline Resilience, tolerance of stress and flexibility & $10 \%$ \\
\hline Analytical thinking and innovation & $0 \%$ \\
\hline Reasoning, problem solving and ideation & $0 \%$ \\
\hline Leadership and social influence & $0 \%$ \\
\hline Solving complex problems & $0 \%$ \\
\hline
\end{tabular}

\section{A. Enabling and Obstructive Factors}

The enabling factor mentioned most frequently by the interviewees was "Leadership driving the transformation", followed by enabling factors synthesized in "Transformation driven Top-down" and "Educating and training". Finally, the interviewees mentioned the following enabling factors least frequently: "Strategy for talent management", "Credibility of senior executives" "Having people on board of 
transformation", "Prioritize what to transform", "Not pursuing immediate benefits" and "Being clear on the purpose of transformation". When reviewing the factors mentioned most frequently, leadership is distinguished as a DT-enabling factor in the organization. It is important for leaders to play a role as DT drivers, as they positively influence people regarding the idea of transformation, and to suggest DT as an indispensable strategic goal for the organization: "The leader also has a role to move, mobilize and motivate. For these changes you need to move and mobilize, people need to be motivated, it is part of the role" (interviewee 5, 9 years of experience).

As an obstructive factor to implement a DT process, interviewees most frequently referred to "People's attitude towards change", followed by the obstructive factors "Market variables affecting the organization" and "Strategy to implement DT". Finally, they mention the following obstructive factors less frequently: "Lack of tools", "Complexity of the transformation project", "Little room for innovation" and "Lack of alignment". In this sense, whether enabling or obstructive, it is clear that DT, in its essence and purpose, requires that the organization not only adapts but also responds in order to be successful, particularly in the case of a rapid evolution of technology. Therefore, the factors mentioned for both categories are mostly related to the critical structure residing in the team of the digital project, which are the basis for achieving a successful DT, and, per team the employees are referred to transversally.

\section{Discussion}

The data showed there is no full consensus regarding the description of DT in the organization under study and reflected on Vacas proposal in which the author recognizes there is confusion in the definition of the term DT [12], partly because organizations interpret digitalization as a technological update of their processes and not as a change in their organizational culture. This viewpoint is shared in the study of Cámara de Comercio de Santiago [10], in which $78 \%$ of companies declared they do not have a DT plan. 
The interviewees indicate that organizations need DT driven by the behavior of clients who require new and better products and services, at lower prices and in less time. These findings are aligned with the study by Tekic et al. and Cámara de Comercio de Santiago $[3,10]$ which posits that the fundamental goals of DT should be to give the client a better experience, innovation in products and new business models. Similarly, Kane et al. [13] asserts that the potential of digital technologies lies in the way in which organizations use them to remodel their businesses.

Regarding the impact of DT on clients, half of the interviewees assert that they have ample benefits; the other half assert that these benefits are limited by the technological affinity and preferences of these clients in their relationship with the organizations. These findings are similar to those of Latinovic [14], who proposes that technologies such as Artificial Intelligence enable organizations to achieve better service experiences for their clients, by giving more customized services of simple interaction and, at the same time, make the organization's operations more efficient.

Undoubtedly, automation or new technologies have an impact on the labor market, which is what the interviewees say when mentioning that the effects of DT will impact the employees not only in terms of what they do (due to the technological change and the new skills these require), but also how they do things when they adopt more flexible and collaborative ways of working such as "Agile Methodologies" [2]. The latter require more contact with the client and the environment. Valderrama [15] agrees with this vision and claims that organizations need to reinvent themselves due to the digital technologies, adopting working models that add agility to the organizations. To this end, talent needs to be transformed. Information needs to be shared internally about the organization's vision and strategic plan for DT, aiming at promoting implementation initiatives, uniting criteria regarding the DT proposal, encouraging employee involvement, making room for innovation and improving the transparency of the DT progress by developing a digital maturity indicator.

Along with processes and tools, people form the basis of any transformation in organizations. In line with this finding, Boutetière et al. [16] indicates several recommendations that would enable to improve the probabilities of success in DT, 
including the development of human capital for the future and education of people in new working methodologies to facilitate its adoption. Illanes et al. [17] estimates, for example, that around $14 \%$ of the workforce may need to reconvert themselves by 2030. The study claims a strong tendency of executives to retrain the workforce due to the need to increase the employees' productivity, though very few executives declare that they are prepared for the challenge, mainly because they do not know what talent they will require in the coming years.

The interviewees are inclined to use external capacities to develop skills that are not present in the organization, maintaining the commitment and understanding of the organization's purpose in the work teams. An additional advantage of this method is that it allows them to be better prepared for talent drain due to key skills in high demand by the market, because knowledge transfer would have been previously planned and ensured. Mahou et al. [18] notes the relevance professionals with scarce profiles have and how rotation of these professionals can obstruct projects, and this factor should therefore be considered as part of the institutional strategy. In the present research, the interviewees were asked about which skill they would enhance regarding the future of work; "flexibility" was the most frequently mentioned, followed by "capacity to adapt", as both skills are key for the adaptation challenge involved in any institutional transformation. In line with this finding, Halpern and Castro [20] proposes a term that links both skills and that, according to them, is to do with the competency of readiness for change.

During the research, participants were shown the projection of growing skills for Latin America [1]. When asked whether they consider them a contribution for the work of the future, a significant majority sustained that they contributed based on what the interviewees themselves understand the phenomenon of DT demands from employees as they perceive it as an adaptation challenge rather than technology. Further on, when asking the interviewees to indicate a preference, they more frequently chose the skill "Emotional Intelligence" as the most relevant [1], followed by "Active learning and learning strategies". In line with this finding, Halpern and Castro [20] asserts that in the coming years the demand for professionals with social and emotional skills will increase as well as the need to foster a continuous-learning 
culture inside organizations. As a solution to the detected gap in terms of skills that will be required in the near future, the following points should be included in the organization's reskilling policy:

1. Establishing a base level of skills for the current roles.

2. Determining the gap of skills less likely to be digitalized in view of the current roles and projects of the organization.

3. Defining the value those skills less likely to be digitalized will supply to the business.

4. Formulating a self-training program in the skills detected in the gap, prioritizing those that add more value.

This investigation detected that the predominant enabling factor in DT is leadership, as the organization leaders are perceived to have the role of DT drivers, positively influencing employees about DT and posing it as a strategic goal for the organization. The finding corresponds to Cámara de Comercio de Santiago [10], where leadership is posited as the most important variable in DT. Boutetière et al. [16] asserts a similar position, though they specify that a leader who is familiar with digital technologies has higher expectations for success in DT, as will those who are dedicated full-time to the transformation process. The findings also indicate that people can frequently be an important obstructive factor in DT because of their resistance to change. Leaders, and people themselves, face a significant challenge in adaptation processes. Likewise, Cámara de Comercio de Santiago [10] asserts that culture (understood as the shared way in which activities are performed within an organization) is a critical element that can boost or slow down DT [2]. Boutetière et al. [16] claim that DT needs, among other things, a cultural and behavioral change, which can be brought about by changing the working patterns within an organization and training people, so they accept the change.

The interviewees were also asked about their main concern regarding DT. An important group (18\%) reported not being concerned about DT as they consider it a positive and necessary phenomenon. Another group (18\%) indicated that DT and its development makes them feel uncertain, especially because they do not know whether the appropriate courses of action are going to be followed to deal with it. In 
this line, Valderrama [15] connects uncertainty with the phenomenon of DT when referring to digitalization as an unpredictable element. Mahou et al. [18] relate it to the capacity leaders need to perform in an environment with uncertainties and, moreover, be able to make information fluid in organizations. When discussing the recommendations by the interviewees to tackle DT, we find that training people is indicated most frequently (34\%). The main recommendation of the interviewees agrees with what Boutetière et al. [16] qualify as one of the influential elements for success of DT, once the organization is clear on the roles and capacities it needs. Similarly, though in terms of occupations more likely to be replaced by technology, WEF [21] concludes in its publication for the OECD that training people helps to move towards occupations less likely to be replaced by technology. To cover this gap, the workforce should be encouraged to actively improve and perfect their skills through self-learning and understand the changing nature of the skills required for DT, which are not exclusively technological. This encouragement should provide for incentives so the business and academic world can jointly develop curriculums of basic skills and update and promulgate them to the population using the means supplied by the emerging technologies.

\section{A. Reference Framework for Pro-Competitiveness Actions in DT Environments}

From the results discussed above, the following specific action plan is proposed as a reference framework for concrete actions to make DT successful, covering educational needs, differential discourses (including practices) and the efficient approach to institutional information asymmetries [3], considering the employees as the natural strength, and success based not only on a financial perspective, but with a historical, political, social and economic context. The action plan is summarized in Table 3. 
Table 3. Action plan pro competitiveness in DT.

\begin{tabular}{|c|c|}
\hline Actions to implement DT & Stage \\
\hline $\begin{array}{l}\text { Strengthening internal communication lines for a DT process } \\
\text { Clarifying the purposes of a DT process } \\
\text { Promoting strategies of DT implementation initiatives } \\
\text { Encouraging employees to become involved } \\
\text { Making room for innovation } \\
\text { Making the process degree of the DT process transparent and } \\
\text { preparing a digital maturity indicator }\end{array}$ & $\begin{array}{l}\text { Characterization of the present and } \\
\text { understanding of reality: Teams } \\
\text { understanding reality in a } \\
\text { multidisciplinary way with a structure } \\
\text { formed by diverse roles and specific } \\
\text { capacities, with clear establishment of } \\
\text { goals and purposes, etc. }\end{array}$ \\
\hline $\begin{array}{l}\text { Determining the gap of skills less likely to be digitalized in view of } \\
\text { the current and projected roles } \\
\text { Establishing an education plan (reskilling policy) of the skills } \\
\text { detected in the gap }\end{array}$ & $\begin{array}{l}\text { High-impact proposal: Continuous } \\
\text { learning according to gaps existing in } \\
\text { the organization (upskilling and } \\
\text { reskilling) }\end{array}$ \\
\hline $\begin{array}{l}\text { Encouraging the workforce to get involved in perfecting skills in } \\
\text { the DT environment } \\
\text { Business and academia jointly implementing programs for the } \\
\text { development of DT-related skills and updating them, using means } \\
\text { supplied by emerging technologies }\end{array}$ & $\begin{array}{l}\text { Alerts on transformations: } \\
\text { Management of available talent, with } \\
\text { clear focus on retaining capacities }\end{array}$ \\
\hline
\end{tabular}

\section{Conclusions}

This work shows that digital transformation has a direct effect on employability in an organization's corporate development but should not necessarily be understood as a cause of extensive job losses. This study presents the perceptions of key stakeholders who are active in DT and establishes that this process reflects the capacity of an organization to position itself, respond and adapt when facing rapid technological changes. A critical structure to make a DT process successful is the human team of the digital process; however, it has not been clearly established how these teams can be created and developed. Today the focus is mainly on "agile" methodologies and processes but there is little clarity about the dynamics required by DT teams, where roles, education and learning, and development of leadership required for a DT process, complex as it is, are addressed. Three lines of action are essential to form DT teams: a) Multi-disciplinary teams understanding reality, composed of diverse roles and specific capacities, with clearly established goals; b) Continuous learning according to gaps existing in the organization and; c) Management of available talent, with clear focus on retaining capacities. To address the detected gaps in organizational behavior, the following lines of action are proposed: 1) Establishing a transversal communicational policy that integrates DT in the organizational culture; 2) Creating a catalogue of fundamental skills that allows 
the company to deploy a self-training program; and 3) Establishing a policy to promote continuous education in the workforce with participation of the business world and the academia. Future research will hopefully show how these lines of action provide an organization with the tools to face DT in practice, and further develop the framework.

\section{AUTHOR'S CONTRIBUTION}

Rolando Rojas-Romero: investigation, writing - original draft.

Héctor Valdés-González: methodology, validation, writing - review and editing.

Lorenzo Reyes-Bozo: validation, writing - review and editing.

\section{REFERENCES}

[1] WEF, The Future of Jobs Report 2018, 2018. https://www.weforum.org/reports/the-future-of-jobs-report$\underline{2018}$

[2] P. J. Guinan, S. Parise, N. Langowitz, "Creating an innovative digital project team: Levers to enable digital transformation,” Business Horizons, vol. 62, no. 6, pp. 717-727, 2019. https://doi.org/10.1016/j.bushor.2019.07.005

[3] Z. Tekic, D. Koroteev, "From disruptively digital to proudly analog: A holistic typology of digital transformation strategies," Business Horizons, vol. 62 no. 6, pp. 683-693, 2019. https://doi.org/10.1016/j.bushor.2019.07.002

[4] R. L. Katz, "Capital humano para la transformación digital en América Latina," CEPAL-Serie Desarrollo Productivo 219, 2018. https://repositorio.cepal.org/handle/11362/43529

[5] L. Gortazar, "Transformación digital y consecuencias para el empleo en España. Una revisión de la investigación Weciente,” Working 2018-04, 2018. https://www.fedea.net/documentos/pubs/dt/2018/dt2018-04.pdf

[6] D. H. Autor, L. Levy, R. J. Murnane, "The Skill Content of Recent Technological Change: An Empirical Exploration," The Quarterly Journal of Economics, vol. 118, no. 4, pp. 1279-1333, 2003. https://doi.org/10.1162/003355303322552801

[7] K. Dengler, B. Matthes, "The impacts of digital transformation on the labour market: Substitution potentials of occupations in Germany," Technological Forecasting and Social Change, vol. 137, pp. 304-316, 2018. https://doi.org/10.1016/j.techfore.2018.09.024

[8] F. Isabella, “¿Qué hacer?: Trabajo, tecnología y regulación social,” Revista Nueva Sociedad, vol. 279, 2019. https://nuso.org/articulo/trabajo-tecnologia-regulacion-social/

[9] OECD, Getting Skills Right: Chile, Getting Skills Right, OECD Publishing, Paris, 2018. https://doi.org/10.1787/9789264293151-en

[10] Cámara de Comercio de Santiago, Desafíos en la Evolución de las Empresas Hacia la Transformación Digital, 2019. https://www.ecommerceccs.cl/el-desafio-hacia-la-transformacion-digital/ 
Digital Transformation: Opportunity or Threat to Employability?

[11] H. J. Rubin, I. S. Rubin, "Interviews as guided conversations," in Qualitative interviewing: The art of hearing data. Thousand Oaks, CA: Sage Publications, 122-144. https://doi.org/10.1177/135638909600200412

[12] F. Vacas Aguilar, "Transformación digital: del lifting a la reconversión," Revista Tecnología, Ciencia y Educación, no. 10, pp. 135-143, 2018. https://doi.org/10.51302/tce.2018.199

[13] G. Kane, D. Palmer, A. Phillips, D. Kiron, N. Buckley, Strategy, not technology, drives digital transformation, MIT Sloan Management Review, Massachusetts, 2015. https://sloanreview.mit.edu/projects/strategydrives-digital-transformation/

[14] Z. Latinovic, S. C. Chatterjee, Customer centricity in the digital age, MIT Sloan Management Review, Massachusetts, 2019. https://sloanreview.mit.edu/article/customer-centricity-in-the-digital-age/

[15] B. Valderrama, "Transformación digital y organizaciones ágiles", Arandu-UTIC Revista Científica Internacional de la Universidad Tecnológica Intercontinental, vol. 6, no. 1, pp. 15-50, 2019.

[16] H. de la Boutetière, A. Montagner, A. Reich, Unlocking Success in Digital Transformations, McKinsey \& Company, 2018. https://www.mckinsey.com/business-functions/organization/our-insights/unlockingsuccess-in-digital-transformations

[17] P. Illanes, S. Lund, M. Mourshed, S. Rutherford, M. Tyreman, Retraining and reskilling workers in the age of automation, McKinsey Global Institute, 2018. https://www.mckinsey.com/featured-insights/future-ofwork/retraining-and-reskilling-workers-in-the-age-of-automation

[18] A. L. Mahou Fernández, S. Díaz Pérez de Lama, "La cuarta revolución industrial y la agenda digital de las organizaciones," Economía Industrial, vol. 407, pp. 95-104, 2018.

[19] J. Bughin, E. Hazan, S. Lund, P. Dahlstöm, A. Wiesinger, A. Subramaniam, Skill Shift: Automation and the future of Workforce, McKinsey Global Institute. McKinsey \& Company, 2018. https://www.mckinsey.com/featured-insights/future-of-work/skill-shift-automation-and-the-future-of-theworkforce

[20] D. Halpern, C. Castro, Estudio de Competencias Digitales, TrenDigital / Cámara de Comercio de Santiago, Cámara de Comercio de Santiago, estudios y publicaciones, 2018. https://www.ecommerceccs.cl/wpcontent/uploads/2018/07/informe-CCS-Competencias-Digitales-1.pdf

[21] WEF, Towards a Reskilling Revolution: Industry-Led Action for the Future of Work, White Papers, 2019. https://www.weforum.org/whitepapers/towards-a-reskilling-revolution-industry-led-action-for-the-future-ofwork

[22] L. Nedelkoska, G. Quintini, "Automation, skills use and training," OECD Social, Employment and Migration Working Papers, No. 202, OECD Publishing, Paris, 2018. https://doi.org/10.1787/2e2f4eea-en

Revista Facultad de Ingeniería (Rev. Fac. Ing.) Vol. 30 (56), e13297. April-June 2021. Tunja-Boyacá, Colombia. L-ISSN: 0121-1129, e-ISSN: 2357-5328.

DOI: https://doi.org/10.19053/01211129.v30.n56.2021.13297 